\title{
The Impact of Extrinsic Motivation on Employees' Performance: A Comparative Analysis of Food and Textile Industries in Sindh, Pakistan
}

\author{
Sumra Haleem Shaikh ${ }^{1}$, Saima Kamran Pathan ${ }^{2}$, Imamuddin Khoso ${ }^{2}$ \\ ${ }^{1} \mathrm{PhD}$ Scholar, Institute of Business Administration, University of Sindh, Jamshoro, Pakistan \\ ${ }^{2}$ Professor, Institute of Business Administration, University of Sindh, Jamshoro, Pakistan \\ Correspondence: Sumra Haleem Shaikh, PhD Research Scholar, University of Sindh, Jamshoro, Pakistan.
}

Received: October 31, 2018

Accepted: November 20, 2018

Online Published: November 21, 2018

doi:10.5539/ibr.v11n12p61

URL: https://doi.org/10.5539/ibr.v11n12p61

\begin{abstract}
The purpose of present study is to examine the effects of external motivational factors on employees. Current study is employed Herzberg's two-factor theory to investigate the effects of extrinsic factors on employees' performance.in food and textile industries of Sindh, Pakistan. Seven point Likert scale is used for survey purpose. Reliability test is conducted for knowing the internal consistency of extrinsic factors as independent variables and employees' performance as dependent variable. Pearson correlation, Analysis Of Variance (ANOVA), $t$ test and multiple regression techniques are employed for data analysis.The results found that all extrinsic factors have positive and significant effects on employees. This study provides good amount of knowledge on the importance of extrinsic factors for improving the employees' performance.
\end{abstract}

Keywords: extrinsic factors, motivation, food industry, textile industry, employee performance

\section{Introduction}

The theme of research is to determine the impact of extrinsic factors on employees' working efficiency. Current study illustrates the association of extrinsic motivation with employees' performance because the factors of extrinsic are playing an imperative role for increasing workers' performance. Therefore, present study demonstrates the effects of extrinsic factors on employees' performance for their goodwill.

Luthan (1998) concluded that motivation is playing a centralization role at place of work to accomplish the desired goals. Motivation means to be encouraged and activated towards an end (Deci \& Ryan, 2002). Motivation is a force to push employees for completion of their tasks. Motivation is associated with every step of life e.g. drinking is motivated by thirst (Deci \& Ryan, 2002). Intrinsic and extrinsic are two types of motivation (Mc Cormick \& Tiffin, 1979). According to Ryan and Deci (2002), intrinsic motivation is related to happiness occurred internally after completion of certain desired tasks. Whereas extrinsic motivation is related to external factors of job itself, which is helpful for improving performance of employees. This study focuses on two-factor theory of Herzberg to evaluate impact of external factors on employee performance. Hygiene factors work as extrinsic factors and contribute a major role to fulfill the basic needs of employees (Khan et al., 2013). According to Cannizzaro et al., (2017), once an organization wants to accomplish a task from workers, they will offer financial rewards along with extrinsic rewards. Organization makes sure to their employees for providing extrinsic rewards when job is properly done (Remi, 2011). Dahlqvist and Matsson (2013) asserted that motivation is a vital tool for increasing the performance of employees and retaining them for longer period in organization. High performance increases the firm's status and position. Extrinsic motivation boosts the employees' performance through good working condition, noble policies, security and reliable relations among peers (Emeka et al., 2015). According to Remi (2011), employees are highly motivated and performed well when they feel interest and pleasure in their job. Security, effective supervision and reliable association among peers in the place of work are approved as important factors that play vital role in boosting performance of the organization.

This paper cover introduction for the research followed by a detailed literature review, scope of the research, research gape, research objectives, research hypothesis \& methodology. In the last, the results of this research work are complied followed by conclusion and come recommendations. 


\section{Literature Review}

Mixed results have portrayed in earlier studies regarding extrinsic motivation and their influence on employee performance. Some previous studies displayed the insignificant impact of few extrinsic factors on workers' performances such as Field et al., (1974), Rahman et al., (2017), Kuvaas et al., (2017), Cannizzaro et al., (2017). Whereas other studies portrayed the insignificant impact of all extrinsic factors on employees' performance such as Mulki et al., (2017), Houston (2010), Hyun S. (2009), Gain et al., (2017). While other studies summarized the significant impact of all extrinsic factors on employees' performance such as Casey et al., (2012), Yuan and Woodman (2010), Stella (2013), Parker et al., (2017), Bear et al., (2017), Ghanbahadur (2014). Recent study has revealed that all extrinsic factors are essential for improving employees' performance. Hur, 2017; Chang and Teng, 2017; Sanjeev and Surya, 2016; Emeks et al., 2015; showed a positive and significant impact of hygiene factors for improving the employee satisfaction, talent and performance in the industry.

Emeka et al., (2015) asserted that all extrinsic factors enhanced the motivation of employees which ultimately influenced positively to performance of workers in terms of productivity. According to Attrams (2013), extrinsic factors were playing a major role for increasing the employee performance in public and private sectors e.g. monetary policy and good working relatives. Hong Tan and Waheed (2011) believed that hygiene factors were more prominence as compared to intrinsic factors in retail industry by applying Herzberg two-factor theory in Malaysia. Their study had more focused on salary then gives importance to company policy and working condition among all extrinsic factors. William (2010) explained that employees were motivated by extrinsic motivation to achieve their high performance in organization. Stella (2008) explained that high motivation and high performance for successful organization can be achieved by numerous variables such as working condition, work relation, supervision and job security in Kitgum District Local Government to carry out good resultant.

\section{Scope of the Study}

Current thesis will help in many areas concerning hospitals, educational institutions and organizations. Present study will offer an awareness about upcoming route. Present thesis will also be supportive for academic's professionals to recognize the dynamic, helpful and supportive relationship amongst external factors with employees' performance.

\section{Research Gap}

Mixed results have portrayed regarding extrinsic motivating factors and their influence on employee performances still modern world. They determined that amongst all extrinsic factors, some factors presented insignificant impact on performances of workers. Current thesis shows that all extrinsic factors are playing a vital role for boost employees' performances.

\section{Research Objectives}

Current study considers subsequent objectives:

I. To estimate the influence of extrinsic motivating factors on performance of employees.

Present objective is supplementary divided into subsequent sub-objectives:

i. To estimate the influence of company policy on performance of employees.

ii. To estimate the influence of work security on performance of employees.

iii. To estimate the influence of supervision on performance of employees.

iv. To estimate the influence of money on performance of employees.

v. To estimate the influence of working condition on performance of employees.

vi. To estimate the influence of relationship with peers on performance of employees.

\section{Research Hypotheses}

Current hypotheses are:

$\mathrm{H} 1=$ The extrinsic motivating factors are significantly related with on performance of employees.

This hypothesis is further split into following sub-hypotheses:

- H1a: Company policy significantly related with performance of employees.

- H1b: Work security significantly related with performance of employees.

- H1c: Supervision significantly related with performance of employees. 
- H1d: Money significantly related with performance of employees.

- H1e: Working condition significantly related with performance of employees.

- H1f: Relationship with peers significantly related with performance of employees.

\section{Research Methodology}

For collecting and analyzing data, research methodology is playing an important role. Quantitative approach has been employed in present thesis. The data was gathered through questionnaires. For this purpose, 385 copies of questionnaire were collected from textile industry and 395 from food industry. Reliability test was conducted through SPSS version 20.0. Descriptive statistics, Pearson correlation, Analysis Of Variance (ANOVA), $t$ test and multiple regression techniques were used for analysis of data. Random sampling technique was used in present study. The selected area is Hyderabad and Karachi Sindh.

\section{Results and Discussions}

In current research, the descriptive analysis (Table 1) for external factors demonstrated that in textile industry, the mean was larger whereas in food industry, the standard deviation was larger as compared to textile industry. The food and textile industries provide the secured job, good company policies, flexible working condition and loyal relation to their employees, which ultimately increase the satisfaction level due to that they take more interest in their work.

According to George \& Mallery (2003), Hyun (2009) and Pallant (2005), acceptable/satisfactory internal consistency of survey is employed for more statistical analysis. As per rule, ranges more than 9 values displays excellent consistency, values in the middle of 9 to 8 expresses good results. From 8 to 7 illustrates acceptable results, 7 to 6 displays questionable results, 6 to 5 indicates poor results and less than 5 confirms unacceptable consistency.

In current research, the reliability test (Table 1) for external factors confirmed that the internal consistency of food industry (combined variables) was .947 and textile industry (combined variables) was .935, which presented satisfactory and excellent outcomes. While individual variables in food industry, company policy, money and working condition revealed the good results whereas work security, supervision and relationship with peers exposed satisfactory acceptable results. The individual variables in textile industry showed satisfactory acceptable results. The satisfied employees are beneficial for sustaining and maintaining the efficiency to achieve the desired goals which ultimately raise the reputation of the industries.

According to Hair et al., (2007), the value amid .9 to 1 indicatess very strong link, .7 to .9 confirms high link, .5 to .7 displays moderate link, .2 to .5 demonstrates small but definite link and .00 to .2 represents slight, almost negligible link.

The Pearson correlation in food industry displayed the positive relation, company policy, supervision, working condition and relationship with peers were medium association whereas money and work security were small affiliation with employee performance while all extrinsic factors were small but definite association with employee performance in textile industry. By comparison of Pearson correlation among food industry and textile industry, present thesis determined that company policy, supervision, working condition and relationship with peers of food industry potrayed the medium relation. The employees of food industry are inspired by extrinsic rewards, which will raise their usage. When products are more used then demands for products will also rise then there will be requests for more products, which will ultimately improve morals of employees by providing facilities to individuals and industries.

Table 1. Descriptive Statistics and Reliability Test

\begin{tabular}{|c|c|c|c|c|c|c|c|c|c|}
\hline & \multicolumn{3}{|c|}{ Combine industries } & \multicolumn{3}{|c|}{ Food industry } & \multicolumn{3}{|c|}{ Textile industry } \\
\hline $\begin{array}{l}\text { Extrinsic } \\
\text { Factors }\end{array}$ & Mean & SD & $\begin{array}{l}\text { Cronbach } \\
\text { alpha }\end{array}$ & Mean & SD & $\begin{array}{l}\text { Cronbach } \\
\text { alpha }\end{array}$ & Mean & SD & $\begin{array}{c}\text { Cronbach } \\
\text { alpha }\end{array}$ \\
\hline $\begin{array}{l}\text { Company } \\
\text { policy }\end{array}$ & 5.4585 & .79229 & .787 & 5.4354 & .82336 & 802 & 5.4823 & .75942 & .768 \\
\hline Work security & 5.4850 & 69837 & .774 & 5.4658 & 72941 & .790 & 5.5048 & 66540 & .754 \\
\hline Supervision & 5.4141 & .76707 & 760 & 5.3899 & 80285 & .778 & 5.4390 & 72874 & 738 \\
\hline Money & 5.4635 & .87264 & 730 & 5.4443 & 91971 & .804 & 5.4831 & 82228 & .752 \\
\hline $\begin{array}{l}\text { Working } \\
\text { condition }\end{array}$ & 5.4801 & .90281 & .801 & 5.4557 & 94785 & .817 & 5.5052 & .85466 & .779 \\
\hline $\begin{array}{l}\text { Relationship } \\
\text { with peers }\end{array}$ & 5.6684 & .64602 & 781 & 5.6641 & .66391 & .744 & 5.6727 & .62797 & .714 \\
\hline $\begin{array}{l}\text { Over } \\
\text { factors }\end{array}$ & 87.9654 & 10.60010 & .942 & 87.6658 & 11.17329 & .947 & 88.2727 & 9.98311 & .935 \\
\hline
\end{tabular}


By comparison of variables among food industry and textile industry, the results found from (Table 2) that independent $t$ test of company policy, supervision, money and relationship with peers of food industry were bigger than textile industry because the workers were become more energetic by achieving higher wages and salaries along with sincere relationship among administration and employees. Whereas work security and working condition of textile industry were larger than food industry because workforce of textile industry was more encouraged and activated, which will increase organization progress in market competitive place that ultimately raises employment and benefits to the individual as well as organization.

Table 2. Regression Analysis

\begin{tabular}{lccc}
\hline & Combine industries & Food industry & Textile industry \\
\hline Extrinsic Factors & Standardized beta (t-value) & Standardized beta (t-value) & Standardized beta (t-value) \\
Company policy & $.026(2.714)$ & $.026(1.958)$ & $.025(1.880)$ \\
Work security & $.041(5.536)$ & $.040(3.892)$ & $.042(3.936)$ \\
Supervision & $.655(42.874)$ & $.656(30.668)$ & $.653(29.930)$ \\
Money & $.110(15.293)$ & $.112(11.172)$ & $.107(10.441)$ \\
Working condition & $.040(3.381)$ & $.038(2.284)$ & $.043(2.501)$ \\
Relationship with peers & $.068(4.791)$ & $.071(3.541)$ & $.066(3.226)$ \\
& & & .566 \\
R square & .571 & .575 & .566 \\
Adjusted R square & .570 & .575 & 920.304 \\
F value & 1900.162 & 978.760 & .000 \\
P value & .000 & .000 & \\
\hline
\end{tabular}

Present study has supported by motivational theories. The Maslow (1954) needs categories like Physiological needs, safety needs and belonging needs, Aldefer (1969) ERG includes existence and relatedness, Mc Clelland's theory (1961) includes affiliation and Herzberg's two-factor theory (1959) includes hygiene factors/extrinsic factors (Swinton, 2006; Bloisi et al., 2007).

\section{Conclusion}

It is concluded that extrinsic factors are key tools within the organization. Food and textile industries enhances and improves the employee's performance by facilitating with training opportunities through which they will increase their status, confidence, style of communication and manage the industrial matters. The result demonstrated that performance of employees is extremely motivated by hygiene factors which created an affirmative link amongst extrinsic factors and employee performance along with good future impact on performance of industries. Present thesis shows the first impression in food and textile industries of Sindh. There is no any its type that measures the impact of extrinsic factors on employee performance of food and textile industries in Kotri, Mitiari and Karachi. Current study recognises at what degree extrinsic factors are influenced. The results suggested that extrinsic factors in food and textile industries provided the opportunities to take an interest in the job and create effective leadership. The employee turnover rate is much lower due to proper and flexible environment. Textile and food industries saves money, make effective products and high profit by concentrating on employees' satisfaction and performance.

\section{Limitation}

Jobs were inattentive for workers, so cooperation from respondents side was less due to terror of organization that action would be taken against by them. In textile industries, teams were facing trouble to provide information regarding the company. In textile industries, there is immoral association among employees and administration, which will create loss of company and employee's turn over that create negative impact to industrial employees.

\section{Recommendations}

Based on our results, certain recommendations are described here: Administration should put emphasis on creating the workplace helpful and favorable so that supervisor have good relations with employees. Employees will take more interest in work, if their jobs will be on permanent base, which will ultimately benefit to organization. Top management should relax the company policy and trust employees. Employee dissatisfaction can be eliminated by applying hygiene factors, so managers should concentrate on it. Extrinsic motivation make the employees more energetic and enthusiasm as far more effective and productive, which ultimately boost the performances of workforce.

\section{References}

Alderfer, C. P. (1969). An Empirical Test of a New Theory of Human Needs. Organizational Behavior \& Human Performance, 4(2), 142. https://doi.org/10.1016/0030-5073(69)90004-X 
Attrams, R. A. (2013). Motivation and Employee Satisfaction: Perceptions of Workers in Public and Private Health Care Facilities. Retrieved from http://ugspace.ug.edu.gh

Bear, G. G., Slaughter, J. C., Mantz, L. S., \& Farley-Ripple, E. (2017). Rewards, praise, and punitive consequences: Relations with intrinsic and extrinsic motivation. Teaching and Teacher Education, 65, 10-20. https://doi.org/10.1016/j.date.2017.03.001

Cannizzaro, D., Stohl, M., Hasin, D., \& Aharonovich, E. (2017). Intrinsic and extrinsic motivation predict treatment outcome in a sample of HIV+ drug user. 171(34). https://doi.org/10.1016/j.drugalcdep.2016.08.106

Casey, R. J., \& Robbins, J. (2012). a Comparison of Motivation of Workers in the United States Versus Nicaragua and Guatemala Utilizing the Hackman and Oldham Job Characteristics Model. International Journal of Business \& Public Administration, 9(3), 39-60.

Chang, J. H., \& Teng, C. C. (2017). Intrinsic or extrinsic motivations for hospitality employees' creativity: The moderating role of organization-level regulatory focus. International Journal of Hospitality Management, 60, 133-141. https://doi.org/10.1016/j.jhm.2016.10.003

Dahlqvist, A., \& Matsson, A. (2013). The impact of extrinsic and intrinsic rewards on employees' motivation: A case study of an insurance company.

Emeka, N., Amaka, O., \& Ejim, E. P. (2015). The Effect of Employee Motivation on Organizational Performance of Selected Manufacturing Firms in Enugu State. World Journal of Management and Behavioral Studies, 3(1), 1-8. https://doi.org/10.5829/idosi.wjmbs.2015.3.1.1314

Feild, H. S., Holley, W. H., \& Armenakis, A. A. (1974). Graduate students' satisfaction with graduate education: Intrinsic versus extrinsic factors. Journal of Experimental Education, 43(2), 8-15. https://doi.org/10.1080/00220973.1974.10806312

Gain, D., \& Watanabe, T. (2017). Unsustainability risk causality in a private industrial forest: An institutional analysis of factors affecting stand ecosystem services in Kochi Prefecture, Japan. Forests, 8(4). https://doi.org/10.3390/f8040126

George, D., \& Mallery, P. (2003). SPSS for Windows Step by Step: A Sample Guide \& Reference.

Ghanbahadur, R. R. (2014). To test the effectiveness of Hygiene-Motivation factors on Irish Accountants and American Engineers in predicting Intrinsic-Extrinsic job satisfaction. Journal of Personnel Psychology, 20, 369-380.

Herzberg, F. H., Mausner, B., \& Snyderman, B. S. (1959). The motivation to work. John Wiley and Sons.

Hong Tan, T., Waheed, A., \& Teck-Hong, T. (2011). Herzberg's motivation-hygiene theory and job satisfaction in the malaysian retail sector: The mediating effect of love of money Herzberg's motivation-hygiene and job satisfaction in the Malaysian retail sector: Mediating effect of love of money. Asian Academy of Management Journal, 16(1), 73-94.

Houston, D. J. (2000). Public-Service Motivation: A Multivariate Test. Journal of Public Administration Research and Theory, 10(4), 713-728. https://doi.org/10.1093/oxfordjournals.jpart.a024288

Hur, Y. (2017). Testing Herzberg's Two-Factor Theory of Motivation in the Public Sector: Is it Applicable to Public Managers? Public Organization Review, 1-15. https://doi.org/10.1007/s11115-017-0379-1

Hyun, S. (2009). Reexamination if Herzberg's two factor theory of motivation in the Korean Arcurrent foodservice operation.

Khan, W., \& Iqbal, Y. (2013). An investigation of the relationship between work motivation (intrinsic \& extrinsic) and employee engagement. A study on Allied Bank of Pakistan.

Kuvaas, B., Buch, R., Weibel, A., Dysvik, A., \& Nerstad, C. G. L. (2017). Do intrinsic and extrinsic motivation relate differently to employee outcomes? Journal of Economic Psychology, 61, 244-258. https://doi.org/10.1016/j.joep.2017.05.004

Luthans, F. (1998). Organisational Behaviour.

Maslow, A., Harold, R. F., \& Cox, R. (1954). Motivation and personality. Motivation and Personality., 1887-1904.

McCormick and Tifflin. J. (1979). Industrial Psychology; New York. 
Mulki, J. P., \& Wilkinson, J. W. (2017). Customer-directed extra-role performance and emotional understanding: Effects on customer conflict, felt stress, job performance and turnover intentions. Australasian Marketing Journal, 25(3), 206-214. https://doi.org/10.1016/j.ausmj.2017.04.002

Parker, S. K., Morgeson, F. P., \& Johns, G. (2017). One Hundred Years of Work Design Research : Looking Back and Looking Forward, 102(3), 403-420.

Rafiq, M., Javed, M., Khan, M., \& Ahmed, M. (2012). Effect of rewards on job satisfaction evidence from Pakistan. Interdisciplinary Journal of Contemporary Research in Business, 4, 337-347

Rahman, K. U., Akhter, W., \& Khan, S. U. (2017). Factors affecting employee job satisfaction: A comparative study of conventional and Islamic insurance. Cogent Business \& Management, 4(1). https://doi.org/10.1080/23311975.2016.1273082

Remi, J. A. (2011). An empirical study of the motivational factors of employee in Nigeria. International Journal of Economics and Finance, 3(5), 227-232. https://doi.org/10.5539/ijef.v3n5p227

Ryan, R. M., \& Deci, E. L. (2002). An overview of self-determination theory. University of Rochester Press

Ryan, R., \& Deci, E. (2000). Self-determination theory and the facilitation of intrinsic motivation. American Psychologist, 55(1), 68-78. https://doi.org/10.1037/0003-066X.55.1.68

Sanjeev, M. A., \& Surya, A. V. (2016). Two-factor theory of motivation and satisfaction: an empirical verification. Annals of Data Science, 3(2), 155-173. https://doi.org/10.1007/s40745-016-0077-9

Stella, O. (2008). Motivation and Work Performance: Complexities in Achieving Good Performance Outcomes; A Study Focusing on Motivation Measures and Improving Workers Performance in Kitgum District Local Government. Istitute of Social Studies, 1-83. https://doi.org/10.1111/j.2044-8295.1969.tb01226.x

William, A. N. (2010). Employee motivation and performance. Ultimate Companion Limited.

Yuan, F., \& Woodman, R. W. (2010). Innovative behavior in the workplace: The role of performance and image outcome expectations. Academy of Management Journal, 53(2), 323-342. https://doi.org/10.5465/amj.2010.49388995

\section{Copyrights}

Copyright for this article is retained by the author(s), with first publication rights granted to the journal.

This is an open-access article distributed under the terms and conditions of the Creative Commons Attribution license (http://creativecommons.org/licenses/by/4.0/). 